\title{
Consolidated Bioprocess for Bioethanol Production from Lignocellulosic Biomass Using Clostridium thermocellum DSM 1237
}

\begin{abstract}
Yunyun Liu, ${ }^{\text {a,b }}$ Xianli Xie,${ }^{\mathrm{a}}$ Wenhuan Liu, ${ }^{\mathrm{a}}$ Huijuan Xu, ${ }^{\mathrm{b}, *}$ and Yunqi Cao ${ }^{\mathrm{a}}$
A consolidated bioprocessing (CBP) using Clostridium thermocellum DSM 1237 for bioethanol production in anaerobic bottles and a $3-L$ fermenter from biomass was investigated. The effects of key operational parameters including different carbon sources, temperature, and substrates on the metabolic performance of the strain were firstly evaluated. It was found that ethanol yield reached $0.60 \mathrm{~g} / \mathrm{L}$ with a cell biomass of $0.80 \mathrm{~g} / \mathrm{g}$ at the optimal temperature of $60{ }^{\circ} \mathrm{C}$ with $0.5 \% \quad(\mathrm{w} / \mathrm{v})$ cellobiose. Further experiments indicated that sugarcane bagasse (SCB) could be utilized to efficiently culture this strain. Ethanol yield reached $0.68 \mathrm{~g} / \mathrm{L}(65.8 \%$ of theoretical yield) from alkali-pretreated SCB. In the subsequent 3-L fermenter trial, the maximum ethanol $0.86 \mathrm{~g} / \mathrm{L}$ (83.3\% of theoretical yield) was achieved, with enzymes enriched in both cellulase and xylanase. The CBP provided enzymes on-site and integrated hydrolysis and fermentation in one-step, which might be an effective approach for economic bioethanol production.
\end{abstract}

Keywords: Clostridium thermocellum; Consolidate bioprocess; Bioethanol; Sugarcane bagasse; Fermenter

Contact information: a: College of Mechanical and Electrical Engineering, Shaanxi University of Science \& Technology, Xi an 710021, China; b: Guangzhou Institute of Energy Conversion, Chinese Academy of Science, CAS Key Laboratory of Renewable Energy, Guangzhou 510640, China;

*Corresponding author:xuhj@ms.giec.ac.cn

\section{INTRODUCTION}

The crisis of climate change coupled with accelerated energy consumption has driven the search for renewable and clean alternative fuels. Conversion of lignocellulosic biomass to ethanol has been considered as a potential solution to solve the energy crisis and environmental pollution problems. Bioethanol technologists aim to use agro-industrial residues as feedstocks that are highly abundant and easily available throughout the world (Lazar et al. 2019).

Lignocellulosic biomass is composed primary of cellulose, hemicellulose, and lignin. Its structure and composition are different according to the substrate species. The biomass recalcitrance (resistance to degradation) currently limits its utilization (Zabed et al. 2017). Generally, the process for bioethanol production from lignocellulosic biomass includes pretreatment, enzymatic hydrolysis, and fermentation (Zhao et al. 2019). The capital cost of pretreatment and production or purchase of enzymes remain the dominant cost hurdles to overcome. Although the expense of enzymes has dropped in the past decades, it still covers about half of the fuel ethanol production cost (Xu et al. 2018; Donato et al. 2019).

Consolidated bioprocessing (CBP) combines cellulose hydrolysis with fermentation of the reducing sugars into one process mediated by a single strain or 
microbial consortium without the aid of commercial cellulase. The use of CBP has attracted increasing attention as an effective and potential solution to reduce ethanol production cost and simplify the operation process. The critical step of CBP is to obtain efficient fermentation strains. Research of CBP has focused on the development of new and effective microorganisms (Blume et al. 2013; Hannah et al. 2017).

C. thermocellum is an aerobic bacterium that was first described by Bayer et al. (1983) and Lamed et al. (1983), and its extensive study began shortly after it was proposed that it could be useful in the direct conversion of biomass into bioethanol.

Previous studies (Lynd et al. 2005; Gupta and Verma 2015; Parisutham et al. 2017) have demonstrated that this kind of strain has a high cellulose decomposition rate and the ability to grow at elevated temperatures $\left(50\right.$ to $\left.60{ }^{\circ} \mathrm{C}\right)$, that can reduce the risk of contamination and produce thermostable enzymes to facilitate the cellulose degradation. These are very important factors in industrial processes. C. thermocellum can produce cellulosomes and a variety of free enzymes to deconstruct the cell wall architecture. The released cellulosomes, or multienzyme complexes, can enhance synergistic actions between different enzymes and contribute to its high rate of cellulose hydrolysis (Olson et al. 2012; Chung et al. 2015; Cui et al. 2019). This thermophilic strain used hydrolysate and carried out fermentation to produce ethanol, hydrogen, and other organic acids. The use of thermophilic strains for the fermentation step at temperature above $50{ }^{\circ} \mathrm{C}$ could avoid the cooling energy consumption that is required when using yeast for ethanol production, and further improve the bioethanol production. Therefore, this anaerobic organism has become an attractive candidate for application in bioconversion of cellulose to bioethanol ( $\mathrm{Li}$ and Zhu 2011; Akinosho et al. 2017).

While $C$. thermocellum has one of the fastest known rates of cellulose hydrolysis, the recalcitrance and low ethanol yield are its leading challenges for industrial-scale ethanol production. Although numerous examinations (Olson et al. 2015; An et al. 2018; Ghosh et al. 2018; Kothari et al. 2019) have obtained a detailed genetic and molecular scheme of the cellulolytic system in $C$. thermocellum, certain aspects of the strain's growth and metabolic characteristics have not been fully revealed. In many natural and industrial fermentation conditions, substrates availability is limited, and the organisms grow at suboptimal rates. Growth performance affects the bioenergetics of bacterial growth and the final fermentation products.

Although microbial free enzymes can deconstruct biomass structures, many bacteria degrade cellulose via enzyme complexes called cellulosomes. The study of the performance and mechanisms of these macromolecular complexes for improving lignocellulosic biomass conversion efficiency using cellulosomes is an ongoing important research topic for commercial utilization of the efficient bacteria. The aim of the present work was to identify the cell-growth behaviors of the thermophilic anaerobic bacterium $C$. thermocellum DSM 1237 by optimizing its growth condition and evaluate its ethanol production performance.

In this study, cellulosic ethanol production by the cultivation of $C$. thermocellum DSM 1237 in anaerobic bottles and a 3-L fermenter with biomass as the substrate were investigated. Cell growth conditions of the strain, including different carbon sources, temperature, and different substrates, and its corresponding ethanol fermentation performance were evaluated. Based on the optimal conditions, the fermenter application tests were performed to achieve high concentration ethanol directly from cellulose using C. thermocellum DSM 1237. 


\section{EXPERIMENTAL}

\section{Materials}

Substrates

Guangxi Fenghao Sugar Co., Ltd. (Yulin, China) provided sugarcane bagasse (SCB). It was pre-milled, screened, and the fractions between 40- and 60-meshes were collected for alkali-pretreatment. The milled bagasse ( $1 \mathrm{~g}$ dry weight) was mixed with 20 $\mathrm{mL}$ of $0.5 \mathrm{M} \mathrm{NaOH}$ (or with $4 \%$ (w/v) peroxide to assist the $\mathrm{NaOH}$ ), and incubated in a water bath at $80{ }^{\circ} \mathrm{C}$ for $2 \mathrm{~h}$ with agitation. After reaction, the treated bagasse was washed with tap water until neutrality and dried at $60{ }^{\circ} \mathrm{C}$ for the subsequent experiments. Other materials, such as corn and rice straw, were collected by Cofco Group Co. LTD located in Shenzhen Guangdong province.

All chemicals and reagents used in this study were ordered from Sigma Aldrich (Shanghai, China) and were of either analytical or molecular grade unless stated otherwise.

\section{Microorganisms and growth medium}

The C. thermocellum DSM 1237 was supported by the German Collection of Microorganisms and Cell Cultures (DSMZ, Braunschweig, Germany) and used throughout this study. It was revived from $-80^{\circ} \mathrm{C}$ before the experiments.

\section{Seed culture}

A modified nutrient medium (Johnson et al. 1981) was used for the activation of the $C$. thermocellum culture with a composition of (per L): $2.60 \mathrm{~g} \mathrm{MgCl}_{2} \cdot 6 \mathrm{H}_{2} \mathrm{O}, 1.30 \mathrm{~g}$ $\left(\mathrm{NH}_{4}\right)_{2} \mathrm{SO}_{4}, 1.43 \mathrm{~g} \mathrm{KH}_{2} \mathrm{PO}_{4}, 5.50 \mathrm{~g} \mathrm{~K}_{2} \mathrm{HPO}_{4}, 0.13 \mathrm{~g} \mathrm{CaCl}_{2} \cdot 2 \mathrm{H}_{2} \mathrm{O}, 6.00 \mathrm{~g} \mathrm{Na}_{2}-\beta$-glycerol phosphate $4 \mathrm{H}_{2} \mathrm{O}, 1.10 \mathrm{~mL} \mathrm{FeSO} \cdot 7 \mathrm{H}_{2} \mathrm{O}$ solution $\left(0.1 \% \mathrm{w} / \mathrm{v}\right.$ in $\left.0.1 \mathrm{~g} / \mathrm{L}\left(\mathrm{NH}_{4}\right)_{2} \mathrm{SO}_{4}\right), 0.25 \mathrm{~g}$ L-Glutathione reduced, 4.50 g yeast extract, $0.5 \mathrm{~mL} \mathrm{Na-resazurin} \mathrm{solution}(0.1 \% \mathrm{w} / \mathrm{v}), 5.0$ $\mathrm{g}$ cellobiose, and $1 \mathrm{~mL}$ resazurin.

This medium composition is the basic solution for activation of the $C$. thermocellum. The initial $\mathrm{pH}$ value of the medium was 7.0. After sterilization at $121^{\circ} \mathrm{C}$ for $20 \mathrm{~min}$, the nutrient medium was immediately transferred to an anaerobic chamber and left for a half day. It was then inoculated with $5 \%$ (v/v) C. thermocellum DSM1237, and cultured at $60^{\circ} \mathrm{C}$ for $48 \mathrm{~h}$. For a seed culture, C. thermocellum was repeatedly transferred over 4 generations continuously for approximately $48 \mathrm{~h}$, and then used as the seed to initiate each fermentation experiment with $5 \%(\mathrm{v} / \mathrm{v})$ inoculum size unless other noted.

\section{Cell growth}

The $C$. thermocellum DSM 1237 was grown anaerobically in a fresh CM3 medium (composition provided by DSMZ) containing (per L): 2.0 g yeast extract, $1.3 \mathrm{~g}\left(\mathrm{NH}_{4}\right)_{2} \mathrm{SO}_{4}$, $1.5 \mathrm{~g} \mathrm{KH}_{2} \mathrm{PO}_{4}, 1.0 \mathrm{~g} \mathrm{MgCl}_{2} \cdot 6 \mathrm{H}_{2} \mathrm{O}, 0.15 \mathrm{~g} \mathrm{CaCl}_{2}, 0.5 \mathrm{~g}$ L-Glutathione reduced, and $1 \mathrm{~mL}$ resazurin, for the inoculant used in all the fermentation experiments. The medium $\mathrm{pH}$ value was adjusted to 7.0 with $\mathrm{NaOH}$ or $\mathrm{HCl}$ and was maintained under an anaerobic atmosphere. 


\section{Consolidated Bioprocessing}

Optimization of cell-growth conditions

Sterile CM3 medium (200 mL culture volume) was prepared for ten groups of parallel experiments (each group with $20 \mathrm{~mL} \mathrm{CM} 3$ medium) under anaerobic conditions. The $\mathrm{pH}$ of the medium was adjusted to the optimal growth value of 7.0 just before inoculation. Freshly prepared C. thermocellum DSM 1237 was added with 5\% (v/v) inoculation in the reaction. Fermentations were performed in $50-\mathrm{mL}$ bottles with supplemented $0.5 \%(\mathrm{w} / \mathrm{v})$ of cellobiose, xylose, and glucose, separately, as carbon sources at $60{ }^{\circ} \mathrm{C}$ for $72 \mathrm{~h}$ to investigate the effect of different carbon sources on the growth of the cell.

The optimization of temperature for cell growth was performed with the same procedure of the above tests using ten groups of parallel bottles with $0.5 \%(\mathrm{w} / \mathrm{v})$ cellobiose as the carbon source. Cell growth and ethanol fermentation performance were assessed by varying the reaction temperature with $50{ }^{\circ} \mathrm{C}, 55^{\circ} \mathrm{C}, 60^{\circ} \mathrm{C}, 65^{\circ} \mathrm{C}$, and $70{ }^{\circ} \mathrm{C}$, separately.

Consolidated bioprocessing with different substrates of raw SCB, alkali-pretreated $\mathrm{SCB}$, and peroxide reinforced alkali-treated SCB, with corn and rice straw as carbon sources were conducted at $60{ }^{\circ} \mathrm{C}$ for $120 \mathrm{~h}$ at $0.3 \%$ (w/v) solids loading to produce ethanol by $C$. thermocellum DSM 1237 . The fermentation process started with autoclaved different carbon sources in 50-mL anaerobic bottles. The carbohydrates consumption and the final ethanol yield were analyzed during the reaction.

Samples were collected at specific time points, and centrifuged at $4{ }^{\circ} \mathrm{C}, 12000 \mathrm{rpm}$ for $10 \mathrm{~min}$ for cell biomass, ethanol, sugars, and acids analysis. All experiments were performed in triplicate, and the given numbers are the mean values.

\section{Fermenter experiment}

The bioreactor experiments were conducted with $8 \mathrm{~g}$ of alkali-treated SCB as the carbon source in 2.5 L of CM3 medium (pH 7.0) at $60{ }^{\circ} \mathrm{C}$ and $150 \mathrm{rpm}$ in a 3-L controlled fermenter (Fig. 1). Before reaction, the system was autoclaved at $121^{\circ} \mathrm{C}$ for $30 \mathrm{~min}$ to keep it in a sterile and anaerobic environment. After $12 \mathrm{~h}, 8 \%(\mathrm{v} / \mathrm{v})$ prepared $C$. thermocellum DSM 1237 medium was inoculated to the system. Continuous nitrogen was fed for 5 min at the beginning of the reaction to exhaust other gases. The $\mathrm{pH}$ value was scrutinized by an on-line monitoring system (Shanghai Baixing Engineering, Shanghai, China). Samples were anaerobically withdrawn at each time interval from culture vessels and separated by centrifugation. The cell-free supernatant was stored at $4{ }^{\circ} \mathrm{C}$ for analysis.

Fig. 1. The 3-L fermenter

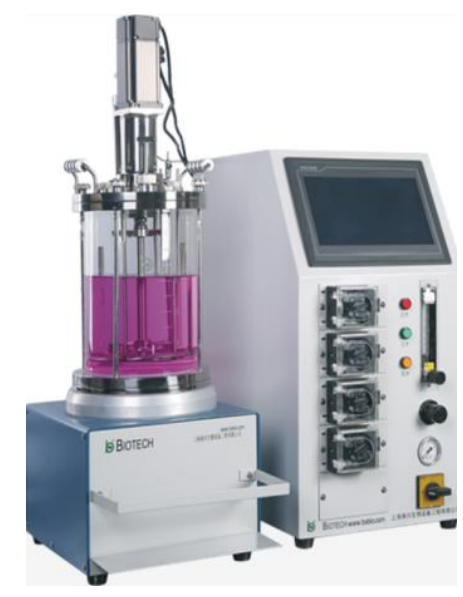

Liu et al. (2020). "Clostridium thermocellum bioethanol," BioResources 15(4), 8355-8368. 8358 


\section{Analytical Methods}

Chemical components of SCB before and after pretreatment, and corn and rice straw were determined according to the standardized methods of the National Renewable Energy Laboratory (NREL, Golden, CO, USA) (Sluiter et al. 2008). Sugars including cellobiose, glucose, and xylose were analyzed by high-performance liquid chromatography (HPLC) using a Shodex sugar SH-1011 column coupled with a refractive index detector (Wilford, Massachusetts, USA). Cellulase FPU activity and xylanase activity were measured by the IUPAC (International Union of Pure and Applied Chemistry) method (Ghose 1987). The protein concentration (biomass) was assayed with the Quick Start Bradford Protein Assay (Thermo Fisher Scientific, Waltham, America) with BSA as the standard (Bradford 1976). Ethanol concentration was measured with a gas chromatograph (Agilent 6820; Agilent Technologies Inc., California, America) equipped with a flame ionization detector (FID) and a fused-silica capillary column (DB-FFAP, $30 \mathrm{~m} \times 0.25 \mathrm{~mm}$ $\times 0.25 \mu \mathrm{m})$. The surface morphology and characteristics of the different residual solids were observed by scanning electron microscopy (SEM). Images were taken using the model JEOL JSM- 4800 LV SEM (Japan Electronics Co. LTD, Tokyo, Japan) and performed at a beam accelerating voltage of $10 \mathrm{kV}$. Digital images were captured using $1280 \times 960$ resolution and $160 \mathrm{~s}$ dwell time. The substrate conversion efficiency was calculated by estimating consumed glucose/xylose equivalents and expressed as a percentage (\%). Ethanol yield from substrate was calculated by grams of ethanol produced divided by grams of glucose/xylose equivalents consumed.

\section{RESULTS AND DISCUSSION}

\section{Cell-growth and Ethanol Fermentation Performance \\ Different carbon sources}

The protein secretion that influences the cell-growth of anaerobic bacteria, such as C. thermocellum, C. cellulolyticum, as well as other cellulase subunits, is dependent on available carbon sources (Cho et al. 2010).

To achieve high density of biomass to promote substrate conversion, $C$. thermocellum DSM 1237 was separately cultured using cellobiose, glucose, and xylose as its carbon sources (Table 1). It was found that cultures containing cellobiose produced more cells, as indicated by the determined higher biomass. The maximum biomass $(0.32$ $\mathrm{g} / \mathrm{g} \mathrm{DM})$ and ethanol $(0.55 \mathrm{~g} / \mathrm{L})$ increased $146.15 \%$ and $19.57 \%$, respectively, when using cellobiose as carbon sources compared to the glucose (biomass $0.13 \mathrm{~g} / \mathrm{g} \mathrm{DM}$ and ethanol $0.46 \mathrm{~g} / \mathrm{L}$ ), based on observations after $72 \mathrm{~h}$ fermentation in $\mathrm{CBP}$ at $60{ }^{\circ} \mathrm{C}$. After reaction, the corresponding residual sugars in $0.5 \%(\mathrm{w} / \mathrm{v})$ of the cellobiose system was $1.22 \mathrm{~g} / \mathrm{L}$, with nearly $75.6 \%$ substrate conversion efficiency. In contrast, the lowest biomass, 0.09 g/g DM, was observed when xylose was used in fermentation with its high residual sugar of $3.39 \mathrm{~g} / \mathrm{L}$. The incomplete utilization of sugars was evident with an increased accumulation of glucose and xylose, leading to a lower ethanol yield.

Similar to ethanol and cell biomass, a remarkable variation in acetic acid concentration from $0.61 \mathrm{~g} / \mathrm{L}$ to $0.33 \mathrm{~g} / \mathrm{L}$ was observed under various carbon sources (Table 1). The high acetic acid was one of the major soluble metabolites produced in fermentation, and it might have noticeable influence on ethanol production. The specific mechanism needs further discussion. Subsequent enzymes detections found that the system was rich in 
both cellulase and xylanase activities with $0.18 \mathrm{FPU} / \mathrm{g}$ and $0.12 \mathrm{IU} / \mathrm{g}$ solids, respectively, which was important for efficient degradation of the substrate.

Table 1. Maximum Growth, Metabolites, and Residual Sugars in CBP from Different Carbon Sources

\begin{tabular}{|c|c|c|c|}
\hline Item & Cellobiose & Glucose & Xylose \\
\hline Biomass (g/g DW) & 0.32 & 0.13 & 0.09 \\
\hline Residual sugars (g/L) & 1.22 & 2.85 & 3.39 \\
\hline Ethanol concentration (g/L) & 0.55 & 0.46 & 0.35 \\
\hline Acetic acid (g/L) & 0.60 & 0.61 & 0.33 \\
\hline Cellulase (FPU/g) & 0.18 & 0.04 & 0.02 \\
\hline Xylanase (IU/g) & 0.12 & 0.07 & 0.04 \\
\hline
\end{tabular}

Maximum growth: When cell biomass achieved highest value; Metabolites: The strain's metabolites include ethanol, acetic acid, cellulose, and xylanase.

The obtained high ethanol and biomass in CBP indicated that C. thermocellum DSM 1237 had improved growth performance with cellobiose as its carbon source (Table 1). Therefore, the subsequent temperature optimization process was carried out with cellobiose as the carbon source based on the above results.

\section{Temperature optimization}

The influence of temperature for the substrate fermentation of $C$. thermocellum DSM 1237 was investigated at the suitable carbon nutrients. As shown in Fig. 2, increasing temperature from $50{ }^{\circ} \mathrm{C}$ to $60{ }^{\circ} \mathrm{C}$ could enhance cell density (Fig. 2A). The maximum biomass $0.80 \mathrm{~g} / \mathrm{g}$ DM and ethanol yield $0.60 \mathrm{~g} / \mathrm{L}$ were obtained under the optimal temperature of $60{ }^{\circ} \mathrm{C}$, and the corresponding residual sugars were $1.51 \mathrm{~g} / \mathrm{L}$ with $69.9 \%$ substrate conversion efficiency. When the temperature was higher than $60{ }^{\circ} \mathrm{C}$, a dramatic drop in ethanol concentration was observed. Further increase in temperature beyond $60{ }^{\circ} \mathrm{C}$ did not increase either cell biomass or ethanol production; rather, it would induce high concentration of acetic acid production (Fig. 2B). Despite the low ethanol production, the bacteria were still able to grow at temperature of $70^{\circ} \mathrm{C}$ with only $0.13 \mathrm{~g} / \mathrm{g}$ cell biomass obtained (Fig. 2A). This lowest growth and ethanol production suggested that the upperlimit of temperature for the strain was below $70^{\circ} \mathrm{C}$, which agreed with the previous reports where the highest temperature of $70^{\circ} \mathrm{C}$ was suggested for the growth of $C$. thermocellum strains upon most occasions (Akinosho et al. 2014).

The detected temperature classified this bacterium as thermophilic and indicated that it was a strong candidate for cellulosic ethanol production. High temperature could reduce the contamination risk in the $\mathrm{CBP}$ process and would produce stable enzymes for motivating their utilization to efficient metabolize the cellulosic biomass. Growth of $C$. thermocellum at $60{ }^{\circ} \mathrm{C}$ was also observed in other studies (Koeck et al. 2015; Singh et al. 2017). To facilitate the subsequent lignocellulosic biomass fermentation process, $C$. thermocellum DSM 1237 was cultured at $60{ }^{\circ} \mathrm{C}$ with different substrates to improve its metabolism efficiency to achieve high ethanol concentrations.

\section{Ethanol production based on different substrates}

Thermophilic anaerobic bacteria are known for their ability to break down plant cell walls using a complex enzyme named cellulosome. Cellulosomes are able to degrade crystalline cellulose and produce soluble sugars that might be transformed into bioethanol

Liu et al. (2020). "Clostridium thermocellum bioethanol," BioResources 15(4), 8355-8368. 8360 
after fermentation. The one-step conversion process using the specific anaerobic strain of C. thermocellum DSM1237 to directly realize the conversion of biomass to ethanol, would reduce the operating cost of cellulosic ethanol.
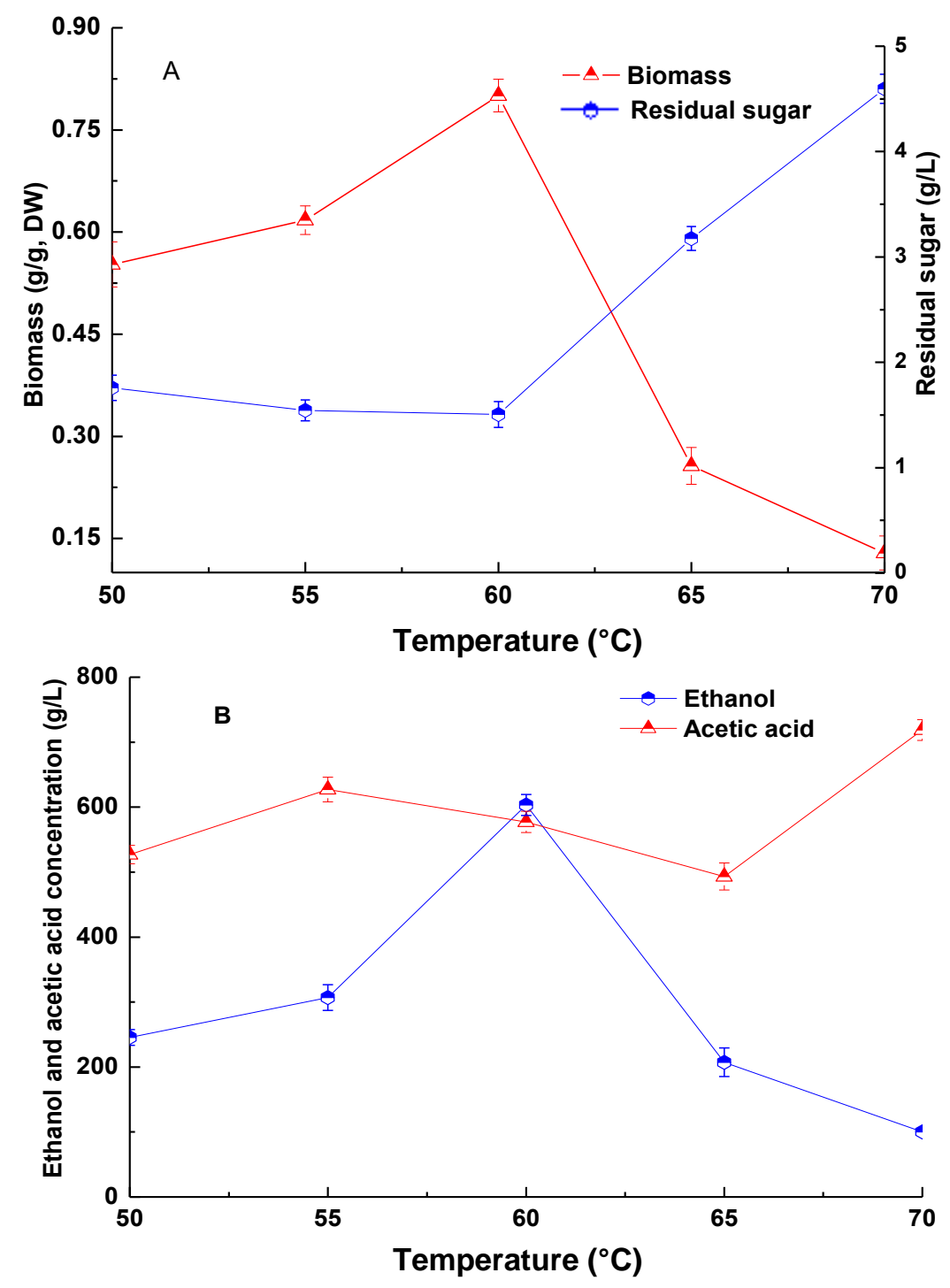

Fig. 2. Effect of different temperatures on (A) biomass residual sugar and $(B)$ ethanol and acetic acid concentration

Based on the above optimized cell growth conditions, SCB, alkali-treated SCB, peroxide enhanced alkali-treated SCB, and corn and rice straw were selected as fermentation substrates to investigate ethanol production performance of $C$. thermocellum DSM1237 under anaerobic conditions at $60^{\circ} \mathrm{C}$. According to compositional analysis using NREL protocol, the SCB used in this study was composed of glucan, xylan, and lignin in percentages of $41.90 \%, 24.68 \%$, and $21.35 \%$, respectively. After pretreatment, the composition was dramatically changed, especially for reinforced pretreatment. Peroxideassisted alkali-treated SCB removed almost $97.85 \%$ lignin, which made cellulose totally exposed and facilitated the subsequent microbial metabolism (Table 2, Fig. 3). The remaining solids are mainly glucan and xylan, and its stubborn chemical structures and 
chemical bonds are broken during reinforced alkali-pretreatment, which facilitate the enzyme to degrade the substrate.

Table 2. Chemical Composition of Different Substrates Before and After Pretreatment

\begin{tabular}{|c|c|c|c|c|}
\hline Samples & Glucan (\%) & Xylan (\%) & $\begin{array}{c}\text { Lignin } \\
(\%)\end{array}$ & $\begin{array}{c}\text { Other Components } \\
(\%)\end{array}$ \\
\hline SCB & 41.90 & 24.68 & 21.35 & 12.07 \\
\hline Alkali-treated SCB & 64.41 & 24.95 & 6.03 & 4.63 \\
\hline $\begin{array}{c}\text { Peroxide-assisted } \\
\text { SCB }\end{array}$ & 69.52 & 23.67 & 0.46 & 4.35 \\
\hline Corn straw & 40.19 & 34.41 & 14.28 & 11.12 \\
\hline Rice straw & 38.47 & 24.10 & 26.10 & 11.33 \\
\hline
\end{tabular}

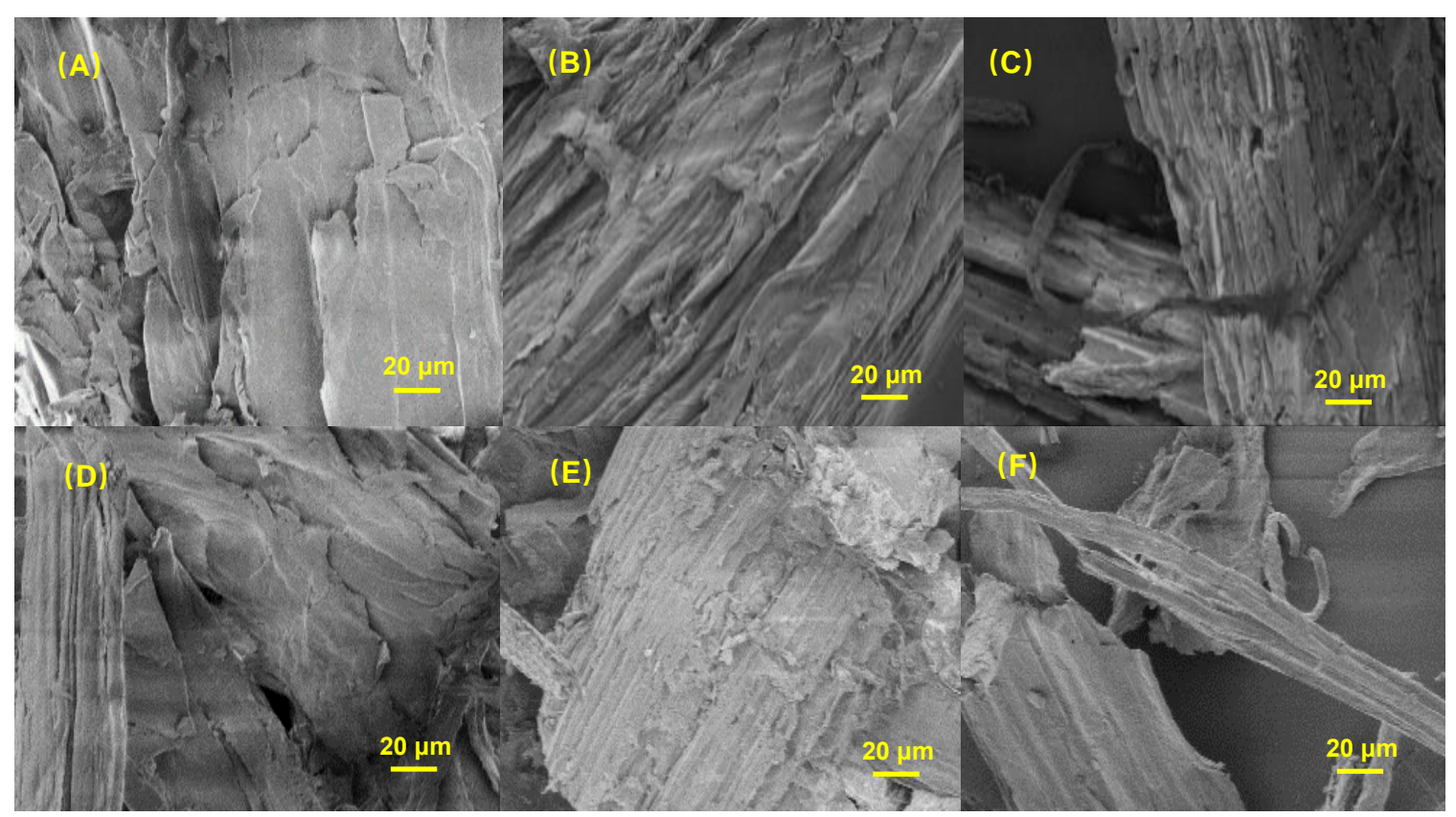

Fig. 3. Scanning electron micrographs of $(A)$ raw, $(B)$ alkali-pretreated, $(C)$ peroxide-assisted alkali-pretreated SCB, (D) raw, (E) alkali-pretreated, and (F) peroxide-assisted alkali-pretreated SCB after fermentation

Culture of the strain was monitored for cell growth over a $120 \mathrm{~h}$ fermentation (Table $3)$. It was found that cell biomass reached $0.75 \mathrm{~g} / \mathrm{g} \mathrm{DM}$ with final ethanol concentration of $0.64 \mathrm{~g} / \mathrm{L}$ (65.5\% theoretical conversion efficiency) using alkali-treated SCB as the substrate, and the final substrate conversion rate was $64 \%$. When the assisted step of peroxide was added to alkali pretreatment, the highest biomass of $0.88 \mathrm{~g} / \mathrm{g} \mathrm{DM}$ and almost $0.68 \mathrm{~g} / \mathrm{L}$ ethanol with a theoretical conversion efficiency of $65.8 \%$ and substrate conversion rate of approximately $69 \%$ were achieved having the reinforced treated SCB as the substrate. For the untreated SCB, corn, and rice straw, the final ethanol yield were relatively lower than the pretreated SCB for their comparatively low enzyme activities produced in reactions in a short time (Table 3 ).

The surface physical structure changes of raw, alkali, peroxide-assisted alkali, and fermented SCB substrates were analyzed by SEM (Fig. 3). C. thermocellum in CBP 
partially changed the surface structures in substrate, especially for the fermented SCB (Fig. 3E and F). The untreated SCB had a compact and smooth morphology (Fig. 1A). Alkalitreated samples showed a rough structure and an obvious gully because of the lignin removal (Fig. 1B). After peroxide reinforced alkali-pretreatment, some smaller fragments were produced (Fig. 1C). These changes improved microbial metabolism efficiency, which was in accordance with the ethanol yield obtained (Table 3), suggesting that most of the substrate had been sufficiently hydrolyzed. It can additionally be found from the residual sugar's concentration (Table 3).

Table 3. Ethanol Fermentation in CBP with Different Substrates

\begin{tabular}{|c|c|c|c|c|c|}
\hline Item & SCB & Alkali-SCB & Alkali+4\% $\mathrm{H}_{2} \mathrm{O}_{2}$ & $\begin{array}{l}\text { Corn } \\
\text { Straw }\end{array}$ & $\begin{array}{l}\text { Rice } \\
\text { Straw }\end{array}$ \\
\hline Biomass (g/g DW) & 0.34 & 0.75 & 0.88 & 0.36 & 0.18 \\
\hline $\begin{array}{l}\text { Residual sugars }(\mathrm{g} / \mathrm{L}) \\
\text { (Cellobiose) }\end{array}$ & 0.46 & 0.62 & 0.51 & 0.12 & 0.19 \\
\hline (Glucose) & 0.18 & 0.33 & 0.23 & 1.16 & 0.04 \\
\hline (Xylose) & 0.00 & 0.13 & 0.19 & 0.11 & 0.01 \\
\hline $\begin{array}{l}\text { Ethanol concentration } \\
(\mathrm{g} / \mathrm{L})\end{array}$ & 0.41 & 0.64 & 0.68 & 0.54 & 0.48 \\
\hline Acetic acid $(\mathrm{g} / \mathrm{L})$ & 1.52 & 0.48 & 0.68 & 0.60 & 0.53 \\
\hline Cellulase (FPU/g) & 0.006 & 0.01 & 0.12 & 0.01 & 0.11 \\
\hline Xylanase (IU/g) & 0.001 & 0.039 & 0.071 & - & - \\
\hline
\end{tabular}

The probable reasons for the noted observations might be that lignin is a key contributor to biomass recalcitrance with cellulases. It influences biomass conversion during CBP. As shown in Table 2, alkali-pretreated SCB could effectively remove much more lignin $(71.8 \%$ ) and retain most of cellulose in the residues of the raw materials, especially for peroxide-assisted alkali pretreatment. The typically used enzymes for ethanol production are cellulases isolated from fungi, in contrast, $C$. thermocellum contains at least 70 enzymes that can alter plant cell wall components and modify the accessibility of the enzymes to cellulose (Munir and Levin 2016). Lignin removal could be beneficial to biomass deconstruction. High molecular weight of lignin has been found to donate electrons to lytic polysaccharide monooxygenases, which is a group of copper-dependent enzymes present in fungi, $C$. thermocellum, and are involved in glycosidic bond cleavage that promote hydrolysis and subsequent fermentation (Westereng et al. 2016). Although structure changes could be observed during controlled CBP (Fig. 3), additional research is still needed to pinpoint its degradation mechanism.

\section{Fermenter Application}

To improve ethanol production from SCB in large-scale fermentation using $C$. thermocellum DSM 1237, a 3-L fermenter trial was conducted under controlled operation parameters at $60^{\circ} \mathrm{C}$ for $56 \mathrm{~h}$ (Fig. 4).

The highest ethanol concentration of $0.86 \mathrm{~g} / \mathrm{L}$ with a theoretical conversion efficiency of $83.3 \%$ from alkali-treated SCB (8 g DM) was achieved in CBP using $C$. thermocellum DSM 1237. The results obtained from the large-scale fermenter operation was comparatively higher than that obtained with the $50-\mathrm{mL}$ bottle tests (ethanol yield 0.68 $\mathrm{g} / \mathrm{L})$. This may be caused by more sugars and enzymes that are produced in CBP with supplemented agitation, which accelerate the substrate mixing, heat, and energy transfer during fermentation, and thus result in the high metabolites (Fig. 4). The corresponding by-

Liu et al. (2020). "Clostridium thermocellum bioethanol," BioResources 15(4), 8355-8368. 8363 
products of acetic acid was increasing with the prolongation of the incubation time. The accumulated acids in fermentation have an inhibitory influence on the formation of ethanol. The effect of acids concentration on ethanol yield will be further discussed in future work.

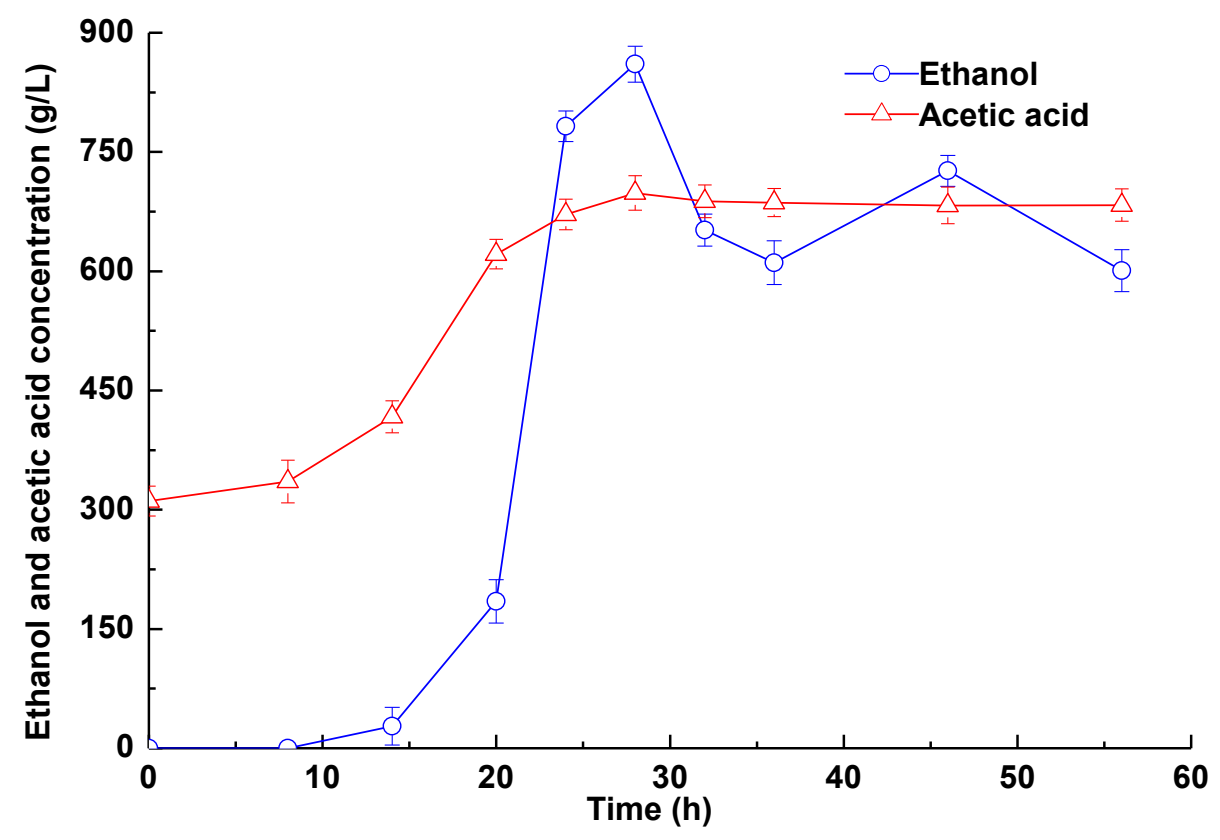

Fig. 4. Ethanol and acetic acid production from alkali-treated SCB in a 3-L fermenter through CBP

During CBP, ethanol production is a final critical factor, and previous studies of the maximum ethanol yield achieved in published experiments are listed in Table 4. Higher ethanol yield usually corresponds to methods that are more complex. Strain adaptability and compatibility are important modifying factors for efficient bioethanol conversion from lignocellulosic biomass and must be investigated case-by-case for each application.

Table 4. Comparison of Maximum Ethanol in CBP with Cellulosic Substrates

\begin{tabular}{|c|c|c|c|c|}
\hline Organism & $\begin{array}{c}\text { Substrate/ } \\
\text { Biomass }\end{array}$ & $\begin{array}{c}\text { Final Ethanol } \\
\text { Concentration }\end{array}$ & $\begin{array}{c}\text { Theoretical } \\
\text { Yield }\end{array}$ & Reference \\
\hline $\begin{array}{c}\text { C. thermocellum } \\
\text { DSM 1237 }\end{array}$ & $\begin{array}{c}\text { Alkali-treated } \\
\text { SCB }\end{array}$ & $\begin{array}{c}0.27 \mathrm{~g} / \mathrm{g} \mathrm{SCB} \\
0.42 \mathrm{~g} / \mathrm{g} \text { glucose }\end{array}$ & $83.30 \%$ & This work \\
\hline $\begin{array}{c}\text { Clostridium strain } \\
\text { AK1 }\end{array}$ & $\begin{array}{c}\text { Cellulose } \\
\text { hydrolysates } \\
\text { from various } \\
\text { biomass }\end{array}$ & 0.16 to $0.34 \mathrm{~g} / \mathrm{g}$ & $66.75 \%$ & Olson (2015) \\
\hline $\begin{array}{c}\text { C. thermocellum/ } \\
\text { C. thermocellum co- } \\
\text { culture }\end{array}$ & $\begin{array}{c}\text { Crystalline } \\
\text { cellulose }\end{array}$ & Up to $4.19 \mathrm{~g} / \mathrm{L}$ & $75 \%$ & $\begin{array}{c}\text { Scully and } \\
\text { Orlygsson } \\
\text { (2015) }\end{array}$ \\
\hline $\begin{array}{c}\text { Thermoanaerobacter } \\
\text { sp. }\end{array}$ & Glucose & $0.32 \mathrm{~g} / \mathrm{g}$ & $83.57 \%$ & $\begin{array}{c}\text { Singh et al. } \\
(2018 \mathrm{~b})\end{array}$ \\
\hline $\begin{array}{c}\text { DBT-IOC-X2 } \\
\text { Sthermocellum }\end{array}$ & $\begin{array}{c}\text { Crystalline } \\
\text { cellulose }\end{array}$ & $22.4 \mathrm{~g} / \mathrm{L}$ & $75 \%$ & $\begin{array}{c}\text { Tian et al. } \\
(2016)\end{array}$ \\
\hline $\begin{array}{c}\text { C. thermocellum } \\
\text { ATCC } 31924\end{array}$ & $\begin{array}{c}\text { crystalline } \\
\text { cellulose }\end{array}$ & $\begin{array}{c}0.30 \mathrm{~g} / \mathrm{g} \\
\text { cellulose }\end{array}$ & $59.71 \%$ & $\begin{array}{c}\text { Singh et al. } \\
(2018 \mathrm{a})\end{array}$ \\
\hline
\end{tabular}

Liu et al. (2020). "Clostridium thermocellum bioethanol," BioResources 15(4), 8355-8368. 8364 
Ethanol conversion from lignocellulosic biomass begins with the intense hydrolysis of substrate structures to obtain high fermentable sugars. Using one-step conversion approach by thermophilic microorganisms can reduce the production costs of cellulosic ethanol. These bacteria can withstand high temperatures, which could reduce contamination risk and produce thermostable enzymes. These all were crucial factors in industrial-scale ethanol production. The 3-L fermenter application using CBP from SCB with $C$. thermocellum DSM 1237 achieved higher (83.3\%) theoretical ethanol yield compared with the related published works under relatively simple operation procedures (Table 4), which was vital for the subsequent scale-up trials.

\section{CONCLUSIONS}

1. Cell biomass of $0.80 \mathrm{~g} / \mathrm{g} \mathrm{DM}$ and ethanol yield of $0.60 \mathrm{~g} / \mathrm{L}$ were obtained in growth media containing $0.5 \%(\mathrm{w} / \mathrm{v})$ cellobiose at $60^{\circ} \mathrm{C}$ after $72 \mathrm{~h}$ of fermentation. The strain was capable to degrade cellulosic biomass, the highest cell biomass of $0.82 \mathrm{~g} / \mathrm{g} \mathrm{DM}$ and ethanol yield of $0.68 \mathrm{~g} / \mathrm{L}$ were achieved when using peroxide-assisted alkalipretreated SCB as the substrate, at $60^{\circ} \mathrm{C}$ for $120 \mathrm{~h}$.

2. In the subsequent 3-L fermenter application, the maximum ethanol yield of $0.86 \mathrm{~g} / \mathrm{L}$ with theoretical conversion efficiency of $83.3 \%$ was achieved. Exploitation of efficient strains in the highly integrated process of CBP might be the most promising strategy for cellulosic bioethanol production.

\section{ACKNOWLEDGMENTS}

This work was supported financially by the Program of Science \& Technology Planning Project of Xi an city (20193039YF027NS027), Natural Science Foundation of Shaanxi Province (2018JQ5134), National Natural Science Foundation of China (51876206), National Key Research and Development Program (2019YFB1503904), State

Key Laboratory for Conservation and Utilization of Subtropical Agro-bioresources (SKLCUSA-b201802), and CAS Key Laboratory of Renewable Energy, Guangzhou Institute of Energy Conversion (Y907k51001).

\section{REFERENCES CITED}

Akinosho, H. O., Yoo, C. G., Dumitrache, A., Natzke, J., Muchero, W., Brown, S. D., and Ragauskas, J. (2017). "Elucidating the structural changes to Populus lignin during consolidated bioprocessing with Clostridium thermocellum," ACS Sustain. Chem. Eng. 5(9), 7486-7491. DOI: 10.1021/acssuschemeng.7b01203

Akinosho, H., Yee, K., Close, D., and Raqauskas, A. (2014). "The emergence of Clostridium thermocellum as a high utility candidate for consolidated bioprocessing applications," Front. Chem. 2, 66-76. DOI: 10.3389/fchem.2014.00066

An, Q., Wang, J. L., Wang, Y. T., Lin, Z. L., and Zhu, M. J. (2018). "Investigation on hydrogen production from paper sludge without inoculation and its enhancement by

Liu et al. (2020). "Clostridium thermocellum bioethanol," BioResources 15(4), 8355-8368. 8365 
Clostridium thermocellum," Bioresource Technol. 263, 120-127. DOI:

10.1016/j.biortech.2018.04.105

Bayer, E. A., Kenig, R., and Lamed, R. (1983). "Adherence of Clostridium thermocellum to cellulose," J. Bacteriol. 156(2), 818-827. DOI: 10.1128/JB.156.2.818-827.1983

Blume, L. R., Noronha, E. F., Leite, J., Queiroz, R. M. L., Ricart, C. A. O., De Sousa, M. V., and Felix, C. R. (2013). "Characterization of Clostridium thermocellum isolates grown on cellulose and sugarcane bagasse," Bioenerg. Res. 6, 763-775. DOI: $10.1007 / \mathrm{s} 12155-013-9295-6$

Bradford, M. M. (1976). "A rapid and sensitive method for quantification of microorgam quantities of protein utilizing the principle of protein-dye binding," Anal. Biochem. 72, 248-254. DOI: https://doi.org/10.1016/0003-2697(76)90527-3

Cho, W., Jeon, S. D., Shim, H. J., Doi, R. H., and Han, S. O. (2010). "Cellulosomic profiling produced by Clostridium cellulovorans during growth on different carbon sources explored by the cohesin marker," J. Biotechnol. 145(3), 233-239. DOI: 10.1016/j.jbiotec.2009.11.020

Chung, D., Cha, M., Snyder, E. N., Elkins, J. G., Guss, A. M., and Westpheling, J. (2015). "Cellulosic ethanol production via consolidated bioprocessing at $75^{\circ} \mathrm{C}$ by engineering Caldicellulosiruptor bescii," Biotechnol. Biofuels 8, Article number 163. DOI: 10.1186/s13068-015-0346-4

Cui, J. X., Olson, D. G., and Lynd, L. R. (2019). "Characterization of the Clostridium thermocellum AdhE, NfnAB, ferredoxin and Pfor proteins for their ability to support high titer ethanol production in Thermoanaerobacterium saccharolyticum," Metab. Eng. 51, 32-42. DOI: 10.1016/j.ymben.2018.09.006

Donato, P. D., Finore, I., Poli, A., Nicolaus, B., and Lama, L. (2019). "The production of second generation bioethanol: The biotechnology potential of thermophilic bacteria," J. Clean. Prod. 233, 1410-1417. DOI: 10.1016/j.jclepro.2019.06.152

Ghose, T. K. (1987). "Measurement of cellulase activities," Pure Appl. Chem. 59(2), 257268. DOI: $10.1351 /$ pac198759020257

Ghosh, S., Holverda, E. K., Worthen, R. S., Lynd, L. R., and Epps, B. P. (2018). "Rheological properties of corn stover slurries during fermentation by Clostridium thermocellum," Biotechnol. Biofuels 11, Article number 246. DOI: 10.1186/s13068018-1248-z

Gupta, A. and Verma, J. P. (2015). "Sustainable bioethanol production from agroresidues: A review," Renew. Sust. Energ. Rev.41, 550-567. DOI:

10.1016/j.rser.2014.08.032

Johnson, E. A., Madia, A., and Demain, A. L. (1981). "Chemically defined minimal medium for growth of the anaerobic cellulolytic thermophile Clostridium thermocellum," Appl. Environ. Microbiol. 41, 1060-1062. DOI: 10.1128/AEM.41.4.1060-1062.1981

Koeck, D. E., Koellmeier, T., Zverlov, V. V., Liebl, W., and Schwarz, W. H. (2015). "Differences in biomass degradation between newly isolated environmental strains of Clostridium thermocellum and heterogeneity in the size of the cellulosomal scaffoldin," Syst. Appl. Microbiol. 38(6), 424-432. DOI:

10.1016/j.syapm.2015.06.005

Kothari, N., Bhagia, S., Zaher, M., Pu, Y. Q., Mittal, A., Yoo, C. G., Himmel, M. F., Ragauskas, A. J., Kumar, R., and Wyman, C. E. (2019). "Cellulose hydrolysis by Clostridium thermocellum is agnostic to substrate structural properties in contrast to fungal cellulases," Green Chem. 21(10), 2810-2822. DOI: 10.1039/c9gc00262f 
Lamed, R., Setter, E., and Bayer, E. A. (1983). "Characterization of a cellulose-binding, cellulase-containing complex in Clostridium thermocellum," J. Bacteriol. 156(2), 828-836. DOI: 10.1128/JB.156.2.828-836.1983

Lazar, M. D., Senila, L., Dan, M., and Mihet, M. (2019). "Crude bioethanol reforming process: The advantage of a biosource exploitation," Ethanol Chapter 10, 257-288. DOI: 10.1016/B978-0-12-811458-2.00010-9

Li, P., and Zhu, M. (2011). "A consolidated bio-processing of ethanol from cassava pulp accompanied by hydrogen production," Bioresource Technol. 102(22), 10471-10479. DOI: 10.1016/j.biortech.2011.08.134

Lynd, L. R., Van Zyl, W. H., McBride, J. E., and Laser, M. (2005). "Consolidated bioprocessing of cellulosic biomass: An update," Curr. Opin. Biotechnol. 16(5), 577583. DOI: 10.1016/j.copbio.2005.08.009

Munir, R., and Levin, D. B. (2016). "Enzyme systems of anaerobes for biomass conversion,” Anaerobes Biotechnol. 156, 113-138. DOI: 10.1007/10_2015_5002

Olson, D. G., McBride, J. E., Shaw, A. J., and Lynd, L. R. (2012). "Recent progress in consolidated bioprocessing," Curr. Opin. Biotechnol. 23(3), 396-345. DOI: 10.1016/j.copbio.2011.11.026

Olson, D. G., Sparling, R., Lynd, L. R. (2015). "Ethanol production by engineered thermophiles," Curr. Opin. Biotechnol. 25(1), 25-35. DOI: https://doi.org/10.1016/j.copbio.2015.02.006

Parisutham, V., Chandran, S. P., Mukhopadhyay, A., Lee, S. K., and Keasling, J. D. (2017). "Intracellular cellobiose metabolism and its applications in lignocellulosebased biorefineries," Bioresource Technol. 239, 496-506. DOI: 10.1016/j.biortech.2017.05.001

Scully, S. M., and Orlygsson, J. (2015). "Recent advances in second generation ethanol production by thermophilic bacteria," Energies 8(1), 1-30. DOI: 10.3390/en8010001

Singh, N., Mathur, A. S., Gupta, R. P., Barrow, C. J., Tuli, D., and Puri, M. (2018a). "Enhanced cellulosic ethanol production via consolidated bioprocessing by Clostridium thermocellum ATCC 31924," Bioresource Technol. 250, 860-867. DOI: 10.1016/j.biortech.2017.11.048

Singh, N., Puri, M., Tuli, D. K., Gupta, R. P., Barrow, C. J., and Mathur, A. S. (2018b). "Bioethanol production potential of a novel thermophilic isolate Thermoanaerobacter sp. DBT-IOC-X2 isolated from Chumathang hot spring," Biomass Bioenerg. 116, 122-130. DOI: 10.1016/j.biombioe.2018.05.009

Singh, N., Mathur, A. S., Tuli, D. K., Gupta, R. P., Barrow, C. J., and Puri, M. (2017). "Cellulosic ethanol production via consolidated bioprocessing by a novel thermophilic anaerobic bacterium isolated from a Himalayan hot spring," Biotechnol. Biofuels 10, Article number 73. DOI: 10.1186/s13068-017-0756-6

Sluiter, A., Hames, B., Ruiz, R., Scarlata, C., Sluiter, J., Templeton, D., and Crocker, D. (2008). Determination of Structural Carbohydrates and Lignin in Biomass, National Renewable Energy Laboratory, Golden, CO, USA.

Tian, L., Papanek, B., Olson, D. G., Rydzak, T., Holwerda, E. K., Zheng, T., Zhou, J., Maloney, M., Jiang, N., Giannone, R. J., et al. (2016). "Simultaneous achievement of high ethanol yield and titer in Clostridium thermocellum," Biotechnol. Biofuels 9, Article number 116. DOI: 10.1186/s13068-016-0528-8

Westereng, B., Cannella, D., Agger, J. W., Jørgensen, H., Andersen, M. L., Eijsink, V. G. H., and Felby, C. (2016). "Enzymatic cellulose oxidation is linked to lignin by longrange electron transfer," Sci. Rep. 5, Article number: 18561. DOI: 10.1038/srep18561 
Xu, Y., Zhang, M., Roozeboom, K., and Wang, D. (2018). "Integrated bioethanol production to boost low-concentrated cellulosic ethanol without sacrificing ethanol yield," Bioresour. Technol. 250, 299-305. DOI: 10.1016/j.biortech.2017.11.056

Zabed, H., Sahu, J. N., Suely, A., Boyce, A. N., and Faruq, G. (2017). “Bioethanol production from renewable sources: Current perspectives and technological progress," Renew. Sust. Energ. Rev. 71, 475-501. DOI: 10.1016/j.rser.2016.12.076

Zhao, Y., Damgaard, A., Xu, Y., Liu, S., and Christensen, T. H. (2019). "Bioethanol from corn stover-Global warming footprint of alternative biotechnologies," Appl. Energy 247, 237-253. DOI: 10.1016/j.apenergy.2019.04.037

Article submitted: May 24, 2020; Peer review completed: September 5, 2020; Revised version received: September 9, 2020; Accepted: September 11, 2020; Published:

September 17, 2020.

DOI: $10.15376 /$ biores.15.4.8355-8368 